\title{
Titanate Nanotubes as Futuristic Catalyst Support Material
}

\author{
Venkataraman Vishwanathan, Lucky Sikhwivhilu
}

\begin{abstract}
Titanate Nanotubes (TNT) were synthesized by aging commercial titanium dioxide ( $\mathrm{TiO}_{2}$ - Degussa $\mathrm{P25}$ ) with an alkali (KOH) solution at different time intervals. The prepared materials were investigated for their surface composition and textural behaviour by X-ray powder diffraction (XRD), Raman spectroscopy, Gas ( $\mathrm{N}_{2}$ and $\left.\mathrm{CO}_{2}\right)$ adsorption measurements, and Transmission electron microscopy (TEM). The $X$-ray diffraction spectra revealed the decrease in the crystalline nature of the materials decreased by exposing them for a longer duration in the base solution. Raman spectra results showed that ageing time affected the structural properties. The specific surface area and the pore size of the newly synthesised materials were affected by the ageing process. The TEM images showed the influence of ageing during the formation of titanate nanotubes. HRTEM revealed that $P d$ particle sizes of $<1 \mathrm{~nm}$ was present inside the tubes.
\end{abstract}

Keywords: Nanotubular; Morphology; Structural Composition; Catalyst Support.

\section{INTRODUCTION}

The structural composition and morphology of various carbon nanotubes and nanofibers have been reported. Titanate nanotubes (TNTs) derived from titanium dioxide have interesting behaviour in surface chemistry in terms of structural changes and morphological differences [1]. Several applications of titanates nanotubes in various industrial products have been reported [2,3]. The importance of tubular form of titanate to be used as a suitable catalytic support material is emphasised further due to its high surface area, thermal stability, and longer life during the course of the reaction [4]. Conventionally sol-gel approach is employed to prepare titanate nanotubes used to synthesize $\mathrm{TiO}_{2}$ based nanotubes using various organic and inorganic templates $[5,6]$. These preparatory routes are and provide more pure and homogeneous products $[7,8,9]$. In all these methods, the difficulty lies in the removal of template after the reaction. Most of the reports have indicated that the treatment with an acid may be a crucial step [10,11]. In our investigation titanate nanotubes were synthesized by using a base $(\mathrm{KOH})$ solution and exposing them at two different time intervals.

Manuscript received on October 07, 2021.

Revised Manuscript received on October 13, 2021.

Manuscript published on October 30, 2021.

* Correspondence Author

Dr. Lucky Sikhwivhilu*, Head and Director of DST/Mintek Nanotechnology Innovation Centre. Engineering and Technology, Botho University, Botswana.

(C) The Authors. Published by Blue Eyes Intelligence Engineering and Sciences Publication (BEIESP). This is an open access article under the CC BY-NC-ND license (http://creativecommons.org/licenses/by-nc-nd/4.0/)
Dr. Venkataraman Vishwanathan, Professor in the Faculty of

The aim of the study was to synthesise the tubular form of titanium dioxide through a simple methodology and to understand their structural composition and surface morphology from the catalyst support point of view using different characterisation techniques techniques.

\section{EXPERIMENTAL}

Titanate nanotubes (TNTs) were synthesied by treating an alkali solution of $\mathrm{KOH}(18 \mathrm{M})$ with a commercially available titania $\left(\mathrm{TiO}_{2}\right)$ (Degussa P-25) sample. The mixture (Titania $+\mathrm{KOH}$ ) was placed in a teflon container and heated at $120^{\circ} \mathrm{C}$ for $20 \mathrm{~h}$ and cooled to room temperature. Two sets of TNT samples were prepared based on two ageing intervals (0 and 61 days). After ageing, the two samples were thoroughly washed with water to remove the base $\mathrm{KOH}$. They were then dried and designated as $\mathbf{T i O}_{2}-\mathbf{B}$ and $\mathbf{T i O}_{2}$ - $\mathbf{C}$ according to the ageing intervals 0 and 61 days respectively. To compare the synthetic samples $\left(\mathrm{TiO}_{2}-\mathrm{B}\right.$ and -C) with Degussa P-25 $\left(\mathrm{TiO}_{2}\right)$ sample, the as-received sample was made into a paste by adding water into it. The dried material was crushed to a desired size, and designated as $\mathbf{T i O}_{2}$-A. To study the influence of metal present inside TNT, Pd metal ( $1 \mathrm{wt} \%)$ was added over $\mathrm{TiO}_{2}-\mathrm{C}$ by impregnating $\mathrm{Pd}\left(\mathrm{CH}_{3} \mathrm{COO}\right)_{2}$. The sample was dried, sieved and designated as CAT-C (i.e. $\mathrm{Pd}(1 \mathrm{wt} \%) / \mathrm{TiO}_{2}-\mathrm{C}$ ).

\section{CHARACTERISATION STUDY}

$\mathrm{X}$-ray diffraction (XRD) profiles of all the materials were studied using recorded on a Phillips PW1830 Diffractometer. Raman spectra of the $\mathrm{TiO}_{2}$ samples were investigated by Jobin-Yvon T64000 spectrometer under a triple subtractive mode. Specific surface area of the samples was determined by the $\mathrm{N}_{2}$ adsorption and desorption measurements at $-195^{\circ} \mathrm{C}$ using an ASAP 2010 porosimeter. The basicity of the samples was measured through adsorption of an acidic molecule $\left(\mathrm{CO}_{2}\right)$ at $27^{\circ} \mathrm{C}$. Transmission electron microscopy (JEOL 100S microscope) was used to understand the morphological features of all the samples The experimental procedure of some of the techniques used were reported earlier [12].

\section{RESULTS AND DISCUSSION}

The synthesis of nanotubular titanate materials from $\mathrm{NaOH}$ have been reported earlier [13,14]. Studies made earlier on the synthesise of nanotubes under base condition have led to sheet like structural formation of titanate nanotubes [15]. However, using a higher concentration of $\mathrm{KOH}$ and ageing for a period of time has shown successful formation of nanotubular titanate (as described in Section 2).

Published By:

Blue Eyes Intelligence Engineering and Sciences Publication (BEIESP)

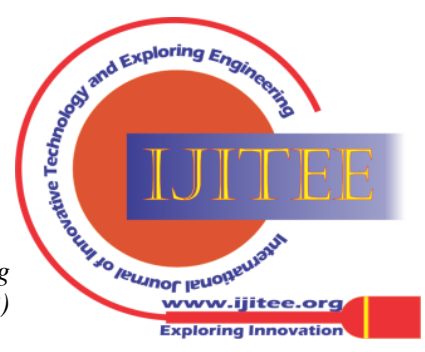




\section{A. X-ray diffraction (XRD) and Raman analysis}

The XRD profiles of $\mathrm{TiO}_{2}$ materials (-A, - $\mathrm{B}$ and $-\mathrm{C}$ ) are shown in Fig.1. The commercial titania $\left(\mathrm{TiO}_{2}-\mathrm{A}\right)$ showed a high crystallinity consisting of a mixture of less rutile and more of anatase phases. However, the material which was only soaked in $\mathrm{KOH}$ solution $\left(\mathrm{TiO}_{2}-\mathrm{B}\right)$ showed amorphous nature with high degree of anatase phase. This indicates that the rutile phase can be reduced or eliminated from the $\mathrm{TiO}_{2}$ sample by a simple treatment with a base solution The diffractogram of $\mathrm{TiO}_{2}$-C showed broad peaks with low intensities. This suggest that the sample has a poor crystallinity and remains amorphous after ageing for a period of 61 days.

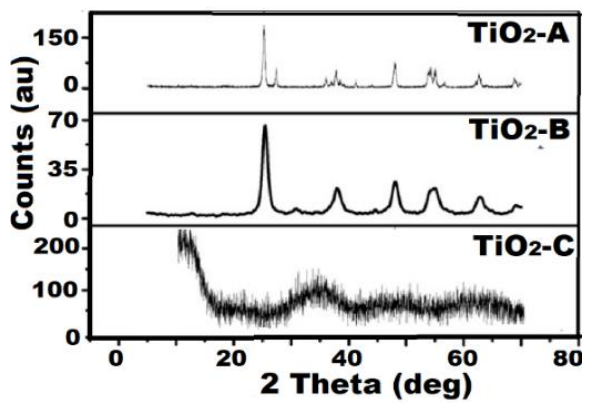

Fig.1. XRD profiles of $\mathrm{TiO}_{2}-\mathrm{A},-\mathrm{B}$, and -C.

The Raman spectra of $\mathrm{TiO}_{2}$-A and -B samples are shown in Fig.2. Broadening of the peak observed for the sample $\mathrm{TiO}_{2}$ A reflects the presence of smaller crystallites. The sharp bands appeared in $\mathrm{TiO}_{2}-\mathrm{B}$ reflects the presence of larger crystallites when $\mathrm{TiO}_{2}$-A was treated with $\mathrm{KOH}$ solution without ageing. The formation of larger crystallites may be due to the rapid reaction of smaller crystallites with the $\mathrm{KOH}$ solution before ageing. The Raman spectrum of sample $\mathrm{TiO}_{2}-\mathrm{C}$

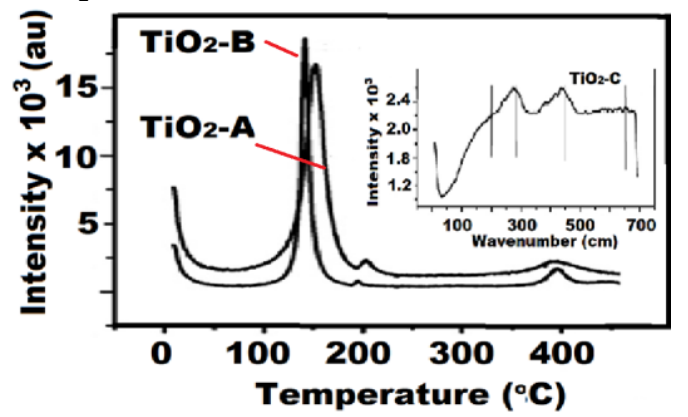

Fig.2. Raman spectra of $\mathrm{TiO}_{2}-\mathrm{A} \&-\mathrm{B}$ and the inset $\mathrm{TiO}_{2}-$ C.

(Fig. 2, inset) shows multiple broad peaks implying the poor crystallinity of the sample. This confirms further with XRD data. The peaks at 188, 271, 441 and $652 \mathrm{~cm}^{-1} 1$ show the existence of titanate species [16,17]. From the EDX investigation, it was found that of $\mathrm{TiO}_{2}-\mathrm{C}$ sample has $19 \%$ potassium ions left after washing with water. This suggests that the titanate nanotubes may have a potassium titanate

\section{B. Surface area analysis}

The surface properties of the samples are reported in Table 1. The surface area values of samples $\mathrm{TiO}_{2}-\mathrm{A}$ and $-\mathrm{B}$ structure [18].

samples has not varied much. However, ageing for 61 days showed

Table 1. Surface properties of both commercial and synthetic $\mathrm{TiO}_{2}$.

\begin{tabular}{|c|c|c|c|c|}
\hline Sample & $\begin{array}{c}\text { Ageing } \\
\text { interval } \\
\text { (days) }\end{array}$ & $\begin{array}{c}\text { Surface } \\
\text { area } \\
\left(\mathbf{m}^{\mathbf{2}} \mathbf{- 1}\right)\end{array}$ & $\begin{array}{c}\text { Pore size } \\
\mathbf{( n m )}\end{array}$ & $\mathbf{p H}$ \\
\hline $\mathrm{TiO}_{2}-\mathrm{A}$ & As received & 50 & 5.9 & - \\
\hline $\mathrm{TiO}_{2}-\mathrm{B}$ & 0 & 52 & 5.4 & 7.76 \\
\hline $\mathrm{TiO}_{2}-\mathrm{C}$ & 61 & 36 & 8.9 & 10.50 \\
\hline $\begin{array}{c}\mathrm{Pd} \\
(1 \mathrm{wt} \%)\end{array}$ & - & 25 & 9.4 & - \\
$/ \mathrm{TiO}$ & & & & \\
\hline
\end{tabular}

a low surface area of $36 \mathrm{~m}^{2} / \mathrm{g}\left(\mathrm{TiO}_{2}-\mathrm{C}\right)$ as compared samples $\mathrm{TiO}_{2}-\mathrm{A}$ and - $\mathrm{B}$. This shows soaking $\mathrm{TiO}_{2}-\mathrm{A}$ in $\mathrm{KOH}$ solution for a longer period transform the smaller crystallite of anatase particles into larger crystallites. The surface area has further decreased after impregnation Pd metal over $\mathrm{TiO}_{2}-\mathrm{C}$ to a value $25 \mathrm{~m}^{2} / \mathrm{g}$. This shows that the palladium particles must have entered the pores of titania. The average pore diameter of $\mathrm{TiO}_{2}-\mathrm{A} \&$-B are very similar (Table 1 ). However, $\mathrm{TiO}_{2}-\mathrm{C}$ and $\mathrm{Pd} / \mathrm{TiO}_{2}$-Cs samples showed a higher value. The $\mathrm{pH}$ values too showed an increase with ageing time resulting in high level of basicity.

\section{Temperature programmed desorption (TPD) studies $\mathrm{CO} 2$}

TPD analysis of $\mathrm{CO}_{2}$ samples were studied to determine the the basic sites and their strength. TPD profiles of $\mathrm{TiO}_{2}-\mathrm{A}$, - $\mathrm{B}$ and $-\mathrm{C}$ are shown in Fig.3. A significant difference in surface basicity was observed in the case of all three samples. The $\mathrm{TiO}_{2}-\mathrm{C}$ sample which was aged for a longer duration in $\mathrm{KOH}$ solution showed the largest $\mathrm{CO}_{2}$ desorption areas.

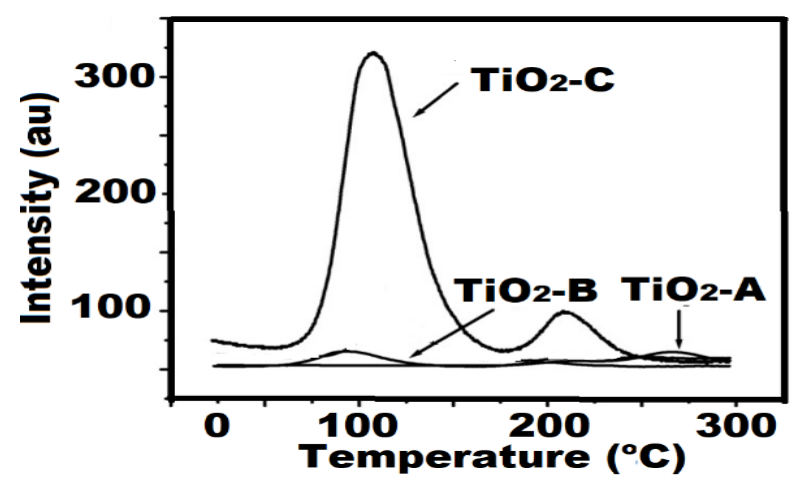

Fig.3. TPD curves profiles of samples $\mathrm{TiO}_{2}-\mathrm{A},-\mathrm{B} \&$-C.

The occurrence of the desorption peaks below $270^{\circ} \mathrm{C}$ attributes to the transformation of few weak basic sites into medium basic sites on the material.

\section{Electron Microscopy studies}

The surface morphology of the samples was analysed by TEM (Fig.4). The sample $\mathrm{TiO}_{2}-\mathrm{A}$ shows agglomeration of smaller crystallites of anatase particles having with an average diameter of

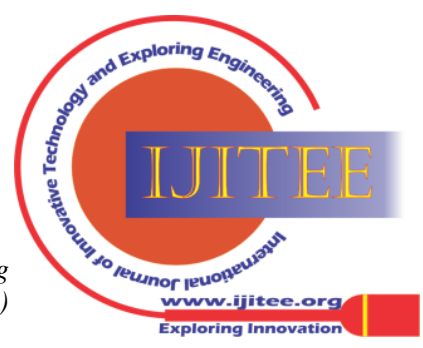




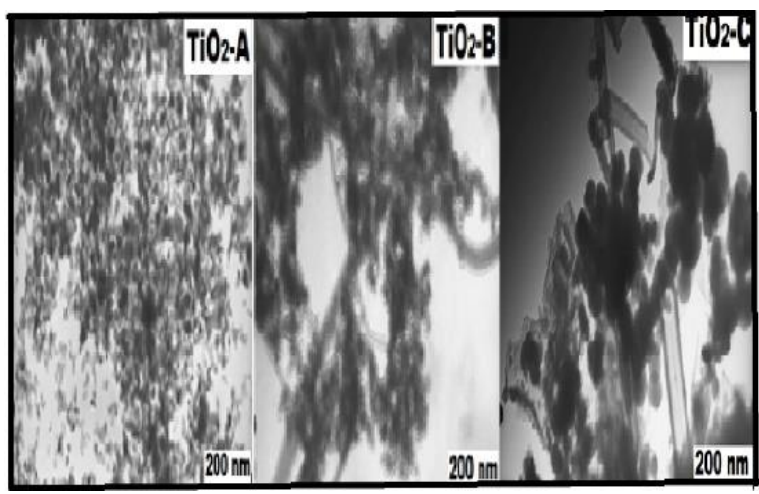

Fig. 4. TEM profiles of $\mathrm{TiO}_{2}-\mathrm{A},-\mathrm{B}$, and -C samples.

$75 \mathrm{~nm}$. $\mathrm{TiO}_{2}-\mathrm{B}$ shows a random distribution of $100 \%$ nanotubes in a diameter range between 8 and $11 \mathrm{~nm}$ and are one hundred to several hundred nanometres in length. The nanotubes appear to be thin walled and open-ended. While $\mathrm{TiO}_{2}-\mathrm{C}$ shows the presence lesser tubes with less crystallinity. The presence of low crystallinity suggests that the nanotubes get dissolved with longer contact time in $\mathrm{KOH}$ solution and make the material more amorphous The presence of tube-like structures may be sheets formed at first which then transformed into tube formation [19]. High resolution TEM of CAT-C (Fig. 5) shows that the nanotubes are aligned in a parallel mode after the addition of $\mathrm{Pd}$ particles over $\mathrm{TiO}_{2}-\mathrm{A}$.

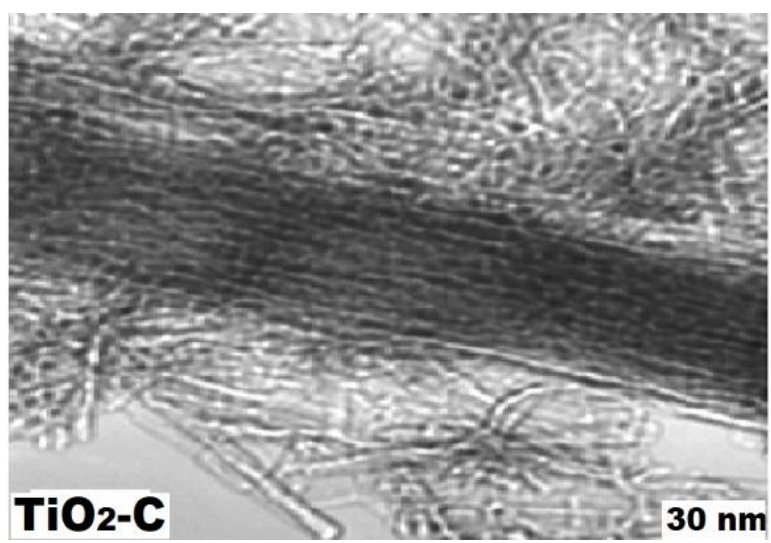

\section{Fig.5. High resolution TEM image of TiO2-C impregnated with 1 wt \% Pd (i.e. CAT-C).}

Further, it revealed that the titanate nanotubes are multiwalled and present in bundles. This agrees well the literature [14]. The formation of nanotubes with acid treatment and the formation mechanism is not understood well [20]. The formation of nanotubes is largely depend on the disordered intermediate phase while in contact with $\mathrm{KOH}$ solution [13]. Based on the present observation, a reaction between $\mathrm{TiO}_{2}$ and $\mathrm{KOH}$ will form $\mathrm{Ti}-\mathrm{O}-\mathrm{K}$ and $\mathrm{Ti}-\mathrm{OH}$ bonds as a primary step. On increasing the contact time in $\mathrm{KOH}$ solution, the material $\mathrm{TiO}_{2}-\mathrm{A}$ rolls into nanotubes. The basicity of the solution plays an important role, and the nanotubes are largely formed below $\mathrm{pH}$ value of 10 . Beyond this, the nanotubes are unstable and become amorphous with ageing time [20].

\section{CONCLUSIONS}

Commercial titania $\left(\mathrm{TiO}_{2}\right)$ sample (Degussa P-25) was used to synthesise titanate Nanotubes (TNT) by treating with a base $\mathrm{KOH}$ solution at two different ageing intervals. The contact time (i.e., ageing) of $\mathrm{TiO}_{2}$ in a concentrated $\mathrm{KOH}$ solution plays an important role in the formation of titanate nanotubes (TNTs). It was observed that ageing for a longer duration $\left(\mathrm{TiO}_{2}-\mathrm{C}\right)$ showed the formation of a well-developed tubular structure with less crystallinity. However, in the absence of ageing, nanosheet type of material with a high degree of crystallinity was formed. It was also noticed that the longer duration of contact time of $\mathrm{TiO}_{2}$ in $\mathrm{KOH}$ solution had a significant influence on both surface area as well as on the pore diameter of titanate nanotubes. TEM and HRTEM images showed the influence of ageing time in the formation of tubular structure of TNT and the presence of Pd particle sizes of $<1 \mathrm{~nm}$ present inside the tubes, respectively.

\section{REFERENCES}

1. Kasuga, M. Hiramatsu and A. Hoson, "Formation of Titanium Oxide Nanotube", Langmuir, Vol.14(12), pp.3160-63, 1998.

2. S. Uchida, R. Chiba, M. Tomiha, N. Masaki and M. Shirai, "Application of Titania Nanotubes to a Dye-sensitized Solar Cell", Electrochemistry, Vol.70(6), pp. 418-420, 2002.

3. M. C. Manique, A. Posteral Silva, A. K. Alves and C. P. Bergmann, "Titanate nanotubes produced from microwave assisted hydrothermal synthesis: characterisation, adsorption and photocatalytic activity", Brazilian J. Chem. Engg., Vol.34(1), pp. 331-39, 2017.

4. C. W. Lai, J. C. Juan, W. B. Ko and S. B. Hamid, "An Overview: Recent Development of Titanium Oxide Nanotubes as Photocatalyst for Dye Degradation”, Int. J. Photoenergy, pp. 1-14, 2014.

5. P. Hoyer, "Formation of titanium dioxide nanotube array", Langmuir, Vol.12(6), pp.1411-13, 1996

6. T. Kasuga, M. Hiramatsu, M. Hirano, A. Hoson and K. Oyamanda, "Preparation of $\mathrm{TiO}_{2}$-based powders with high photocatalytic activities", J. Mater. Res., Vol.3, pp. 607-609, 1997.

7. J.H. Jung, H. Kobayashi, K.J.C. Van Bommel, S. Shinkai and T. Shimizu, "Creation of novel helical ribbon and double-layered nanotube $\mathrm{TiO}_{2}$ structures using an organogel template", Chem. Mater., Vol.14(4), pp. 1445-1447, 2002.

8. H. Imai, Y. Takei, K. Shimizu, M. Matsuda and H. Hirashima, "Direct preparation of anatase $\mathrm{TiO}_{2}$ nanotubes in porous alumina membranes", J. Mater. Chem. Vol.9, pp.2971-2972, 1999 9. S.M. Liu, L.M. Gan, L.H. Liu, W.D. Zheng and H.C. Zeng, "Synthesis of single-crystalline $\mathrm{TiO}_{2}$ nanotubes", Chem. Mater., Vol.14(3), pp.1391-1397,2002.

9. 10. T. Kasuga, M. Hiramatsu, A. Hoson, T. Sekino and K. Niihara "Titania Nanotubes Prepared by Chemical Processing", Adv.Mater. (15), pp.1307-1311, 1999.

10. 11. V. Idakiev, Z.-Y. Yuan, T. Tabakova and B.-L. Su, "Titanium oxide nanotubes as supports of nano-sized gold catalysts for low temperature water-gas shift reaction", Appl. Catal. A: Gen., Vol.281(1-2), pp.149-155, 2005.

11. 12. Ashish Kumar, V. P. Kumar, B. P. Kumar, V. Vishwanathan and K. V. R. Chary, "Vapaour phase oxidation of benzyl alcohol over gold nanoparticles supported on mesoporous TiO2", Catal. Lett., Vol.144, pp.1450-1459, 2014

12. 13. Q. Chen, W. Zhou, G. Du and L.-M. Peng, "Trititanate nanotubes made via a single alkali treatment”, Adv. Mater., Vol.14(17) pp.1208-1211), 2002.

13. 14. H. Peng, G. Li and Z. Zhang, "Synthesis of bundle-like structure of titania nanotubes”, Mater. Lett., 59(10), pp.1142-45, 2005.

14. 15. X. Sun, X. Chen and Y. Li, "Large-scale synthesis of sodium and potassium titanate nanobelts", Inorg. Chem., 41(20), pp.4996-4998, 2002

15. 16. X.-Y. Liu and N.J. Coville, "A Raman study of titanate nanotubes", South African J. Chem., Vol.58, pp. 110-113, 2005.

16. 17. S. Uchida, R. Chiba, M. Tomiha, N. Masaki and M. Shirai, "Hydrothermal Synthesis of Titania Nanotube and its Application for Dye- Sensitized Solar Cell”, Stud. Surf. Sci. Catal., Vol146, pp.791794, 2003.

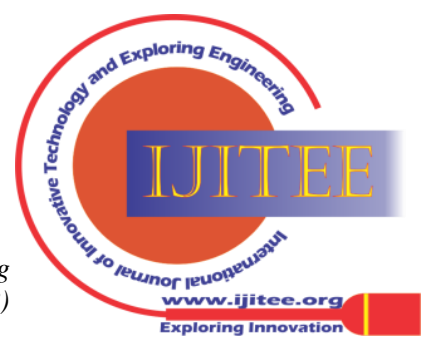


17. 18. N. Masaki, S. Uchida, H. Yamane and T. Sato, "Characterization of a new potassium titanate, $\mathrm{KTiO}_{2}(\mathrm{OH})$ synthesized via hydrothermal method", Chem. Mater., Vol.14(1), pp.419-424, 2002.

18. 19. B.D. Yao, Y.F. Chan, X.Y. Zhang, Z.Y. Yang and N. Wang, "Formation mechanism of TiO2 nanotubes", Appl. Phys. Lett., 82(3), pp.281-283, 2003.

19. 20. S.-H. Chien, Y.-C. Liou and M.C. Kuo, "Preparation and characterization of nanosized Pt/Au particles on $\mathrm{TiO}_{2}$-nanotubes", Synth. Met., 152(1-3), pp.333-336, 2005.

\section{AUTHORS PROFILE}

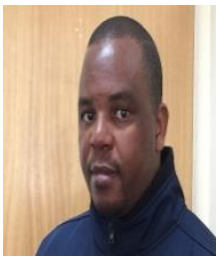

Dr. Lucky Sikhwivhilu is the current Head and Director of DST/Mintek Nanotechnology Innovation Centre. He received his $\mathrm{PhD}$ in Chemistry from the University of the Witwatersrand. He has post-doctoral experience from Unipress - Institute of High-Pressure Physics of the Polish Academy of Sciences, and University of Warsaw, Poland. He is currently the chairperson and founding member of the South African Solar Energy Association (SASEA). He has also founded Nanotechnology Young Researcher Symposium (NYRS). He is the current leader of Technical Committee, JWG 1 group (Terminology and Nomenclature) - ISO TC 229 Nanotechnologies. He serves as advisory panel member of NPEP and served in the executive committee of SANi. Headed India-Brazil-South Africa (IBSA) Nanotechnology Trilateral Initiative (Health, Energy, Water, and Advanced Materials and Sensors). He is the editor of South African Journal of Chemistry and Current Chinese Science. Has contributed over 50 research articles, several trade secrets and a patent. Has supervised several Hons, MSc, PhD and Post-docs. Has won several awards and is a member of American Chemical Society and others. [luckys@mintek.co.za]

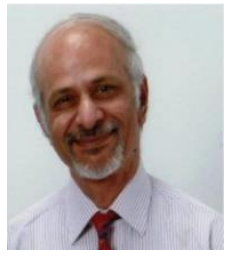

Dr Venkataraman Vishwanathan, had obtained his Bachelor's and Master's degrees in Chemistry from the University of Poona, India and Doctor of Philosophy (Ph.D) from the University of Bradford, England in 1978. He was a teaching-cum-research faculty at the Lakehead University / Canada and University of West Indies (UWI) / Jamaica. He had a long spell as Research Investigator on few missionbased projects while working as a Deputy Director at Indian Institute of Chemical technology (IICT), Hyderabad/India. He has more 75 research papers published in peer reviewed journals to his credit including one in the prestigious journal Nature $(280$, pp.308, 1979). He has guided 17 students for their doctoral degrees. Presently, he is a Professor in the Faculty of Engineering and Technology at Botho University. [venkataraman.vishwanathan@bothouniversity.ac.bw]

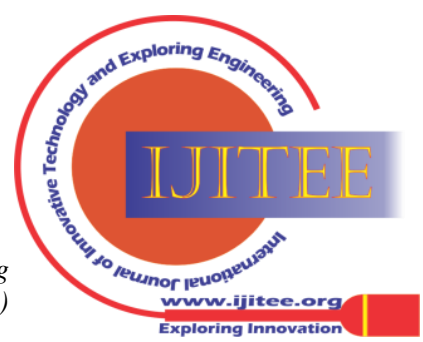

